Relations industrielles

Industrial Relations

\title{
Recruitment and Selection in Canada, Victor M. Catano, Willi H. Wiesner, and Rick D. Hackett (2016) Toronto: Nelson \\ Education, sixth edition, 543 pages. ISBN: 978-0-17-657031-6
}

\section{Stéphanie Maillet}

Volume 72, numéro 1, hiver 2017

URI : https://id.erudit.org/iderudit/1039600ar

DOI : https://doi.org/10.7202/1039600ar

Aller au sommaire du numéro

Éditeur(s)

Département des relations industrielles de l’Université Laval

ISSN

0034-379X (imprimé)

1703-8138 (numérique)

Découvrir la revue

Citer ce compte rendu

Maillet, S. (2017). Compte rendu de [Recruitment and Selection in Canada, Victor M. Catano, Willi H. Wiesner, and Rick D. Hackett (2016) Toronto: Nelson Education, sixth edition, 543 pages. ISBN: 978-0-17-657031-6]. Relations industrielles / Industrial Relations, 72(1), 210-212.

https://doi.org/10.7202/1039600ar

Tous droits réservés (C Département des relations industrielles de l’Université Laval, 2017
Ce document est protégé par la loi sur le droit d'auteur. L'utilisation des services d'Érudit (y compris la reproduction) est assujettie à sa politique d'utilisation que vous pouvez consulter en ligne.

https://apropos.erudit.org/fr/usagers/politique-dutilisation/ 
remis en cause. En effet, quel sens donner au travail lorsque celui-ci ne suffit plus à s'affranchir de la précarité ni à garantir la participation à la vie civique?

Dans le troisième chapitre, I'auteure s'applique à montrer que la remarchandisation du travail n'est pas seulement la conséquence attendue de la polarisation de l'emploi et de l'incapacité de certains à se requalifier dans un marché exigeant des compétences de plus en plus spécialisées. Dans les faits, elle serait davantage le fruit d'une idéologie gestionnaire fondée sur la naturalisation du marché, c'est-àdire sur l'idée que le marché est une force quasi naturelle qu'il ne faut pas chercher à maîtriser. Ce qu'on appelle l'idéologie gestionnaire n'agit pas seulement sur le plan économique. En s'attardant au rôle joué par l'État dans la promotion de la marchandisation du travail (chapitre 4), l'auteure indique aussi que cette idéologie a des conséquences importantes sur le plan politique. Dans un marché naturalisé, il ne saurait être question de citoyens, mais d'entrepreneurs responsables de leur sort. Autrement dit, il devient plus commode pour nos gouvernements d'adopter le lexique économique et de faire l'économie des discours portant sur les valeurs civiques. On parlera alors de contrats entre partenaires et de gestion du risque, pas de droits et de libertés.

En pratique, la naturalisation du marché vient justifier les pratiques visant à faciliter l'adaptation des entreprises au marché, ce qui se traduit par la promotion du travail atypique, par des politiques flexi-sécuritaires et par une précarisation des travailleurs. $C^{\prime}$ est ce qui fera dire à Yerochewski que c'est «dans ce sens-là qu'on peut parler de la 'fin d'un compromis tacite' visant à maîtriser les forces du marché »(p. 109). Sans surprise, l'auteure conclut que la remarchandisation du travail modifie considérablement les conditions de lutte des travailleurs, qui doivent composer avec I'individualisation du travail, I'atomisation du temps social, ainsi qu'avec des mesures de protection sociale diminuées. Dans ces circonstances, il ne faut plus compter sur les mécanismes traditionnels de défense et de représentation, qui, en épousant la trajectoire de la société salariale, s'inscrivent dans le modèle de la relation standard d'emploi. Yerochewski propose plutôt de repenser le travail en recherchant des «formes de démocraties plus appropriées pour refléter la multiplicité des voix qui aspirent à refonder les notions d'égalité et de justice sociale» (p. 155).

Quand travailler enferme dans la pauvreté et la précarité constitue une contribution positive aux débats portant sur les effets néfastes des nouvelles formes d'organisation du travail. À ce titre, il s'inscrit dans la même foulée que les travaux de Cranford (2003), Fudge (2006), Vosko (2009) et Coiquaud (2011), que Yerochewski cite d'ailleurs fréquemment.

\section{Frédérick Plamondon \\ Doctorant \\ Département des relations industrielles Université Laval}

\section{Recruitment and Selection in Canada}

Victor M. Catano, Willi H. Wiesner, and Rick D. Hackett (2016) Toronto: Nelson Education, sixth edition, 543 pages. ISBN: 978-0-17-657031-6.

This science-based book is part of the Nelson Education series in human resources management (HRM) and provides a comprehensive account of the best practices in recruitment and selection of talent in a Canadian context. This thoroughly researched, up-to-date and well-structured book, written by Victor M. Catano, Willi H. Wiesner and Rick D. Hackett, and edited by Monica Belcourt, addresses current and progressive scientific, theoretical, legal and practical elements of recruitment and selection in Canada.

In today's rapidly changing, unpredictable and competitive organizational environments, organizations should be staffed 
with people capable of performing their assigned roles and responsibilities. In order to accomplish this goal, HRM professionals must stay acquainted with the latest advancements applicable to Canadian organizations through continuous learning. This book offers easy-to-read, reliable, valid, and up-to-date knowledge of the current issues and practices that are used in recruiting and selecting employees within a Canadian context. Each of the chapters describes current thinking based on the most recent theorizing and research as reflected in the HR literature. Chapter 1 introduces the importance and relevance of recruitment and selection to Canadian organizations, and examines the relationship between legislative requirements and the social/economic environment that plays an important role in this process. Chapter 2 begins with an illustration of a typical hiring process and goes on to examine basic concepts of reliability and validity that underlie current recruitment and selection practices. Chapter 3 presents an overview of the key legislation and legal requirements that affect the practice of recruitment and selection in Canada, exemplified with the most significant cases that have had a major impact on recruitment and selection. Chapter 4 discusses the relevance of job and work analyses, as well as competency models, to HR development. Chapter 5 examines job-related performance and measures as integral criteria in building and validating selection systems that will meet professional and legal standards. Chapter 6 reviews the role of recruitment in the overall HR strategy, while chapter 7 introduces procedures commonly used in applicant screening. Then, chapter 8 covers the testing methods in HR selection, administered to the screening process survivors, and provides information on the technical, ethical, and legal requirements governing their use. Chapter 9 focuses on new and effective alternatives to traditional employment interviewing.
Finally, chapter 10 addresses subjectivity and error in selection decisions.

The sixth edition of Recruitment and Selection in Canada should be a key referent for HRM professionals looking to design recruitment and selection policies, and practices that not only meet scientific, professional and legal standards, but also are effective in supporting organizational strategies and creating solutions for the effective management of people. However, its content is not only useful to professionals, but is also designed to meet the needs of instructors and students of all academic levels. Indeed, Recruitment and Selection in Canada allows for in-depth understanding of the content by including learning outcomes at the beginning of each chapter, and both exercises and case material at the end of each chapter to illustrate important principles and concepts in a context of application. Furthermore, scientific and professional examples of the best practices used by Canadian companies that are leaders in HRM, and relevant websites and interactive material are referenced throughout the text, which provides opportunities for further discussion and analysis in classroom settings. Moreover, the Nelson Education Teaching Advantage (NETA) program delivers research-based instructors resources, which allow a personalized teaching and learning experience. Instructors have access to online tools in order to customize lectures and presentations, such as a an instructor's manual, a secure online testing system, lectures slides, digital copies of figures, short tables, and photographs used in the book as well as MindTap, a single Learning Path that guides students through the curriculum.

The intent of the authors is to "present those 'best practices' that will lead to the staffing of organizations with the best-qualified candidates" (p. 4). Mission accomplished...for the most part. I would have liked a section of the book, if not a full chapter, dedicated to the application of 
human resources information systems (HRIS) in respect to recruitment and selection practices. While HRIS is briefly broached, it is not sufficiently addressed given its crucial role in today's technology-based business environments. While I regard this as an important shortcoming, I nonetheless recommend Recruitment and Selection in Canada as an imperative referent for all individuals interested in Canadian human resources management.

\section{Stéphanie Maillet \\ Professor \\ Département d'administration \\ Université de Moncton}

\section{Réguler l'économie: l'apport des organisations patronales}

Dirigé par Danièle Fraboulet, Michel Margairaz et Pierre Verrus (2016) Rennes:

Presses universitaires de Rennes,

Coll. Pour une histoire du travail, 340 pages. ISBN : 978-2-7535-4757-5.

Ce livre est le fruit d'un programme de recherche pluridisciplinaire et internationale, mené pendant sept ans, sur les organisations patronales en Europe. II analyse le rôle des organisations patronales dans la régulation économique et financière en Europe durant les $19^{\mathrm{e}}$ et $20^{\mathrm{e}}$ siècles. Plusieurs questions inspirent cet ouvrage, mais la question principale s'avère la suivante: "De quelle manière les organisations patronales ont participé à la modification du contenu, de la hiérarchie et du poids relatif des règles?». Les réponses à ce questionnement se trouvent dans 28 chapitres, regroupés en deux grandes parties et rédigés par plusieurs mains. La première partie examine la régulation économique par l'État et par le marché, alors que la deuxième partie aborde la régulation économique par branche et par secteur.

Avant de commencer, il est intéressant de souligner que la définition d'organisation patronale utilisée par les auteurs est large. Certaines organisations sont des associations, par exemple, la Société industrielle de
Mulhouse, tandis que d'autres constituent des cartels, tel le Cartel des peigneurs de laine de Roubaix-Tourcoing.

De facto, les auteurs montrent l'importance du rôle joué par les organisations patronales dans les sphères économique, juridique et politique. Certaines organisations ont contribué à la définition de la qualité des produits, ainsi qu'à la fixation des prix et des tarifs. Citons, par exemple, les Organisations patronales des soies de Lyon qui ont contribué d'une manière très significative à mettre en place des règles et des usages susceptibles de réduire les coûts de transaction et l'incertitude dans le but de définir et de contrôler la qualité des soies, de lutter contre la fraude, d'améliorer l'information sur les marchés et entre les partenaires commerciaux, de défendre le protectionnisme, etc. Citons, également, le Cartel des peigneurs de la laine de Roubaix-Tourcoing qui a mis en place un système d'engagement visant à supprimer la concurrence, à freiner la surproduction et à instaurer une solidarité entre les membres du cartel. De même, dans l'industrie européenne des câbles, I'International Cable Development Corporation a imposé des normes techniques, des contingents nationaux, des quotas d'exportation, ainsi que des mesures de contrôle des prix. Dans le secteur tertiaire, les organisations patronales suisses ont pu imposer un système durable de régulation de la concurrence. Cette réussite est liée en grande partie au soutien de l'État. En effet, «la Suisse offre un bon exemple remarquable de coopération entre les organisations professionnelles, les cartels et l'État». Toutefois, l'objectif du système suisse était de fixer des règles dans le but de réaliser un «optima au sens de Pareto».

Il y est mentionné, également, que l'Association italienne des hôteliers a réduit les coûts de production à travers la régulation du «marché du travail» et a adopté un système de prix transparent qui a permis de réduire la concurrence par la publicité des prix. En effet, le rôle de l'État est plus déter- 